\title{
Rno_circ_0001004 Acts as a miR-709 Molecular Sponge to Regulate the Growth Hormone Synthesis and Cell Proliferation
}

\author{
Jiali Xiong ${ }^{\dagger}$, Haojie Zhang ${ }^{\dagger} \ddagger$, Yuxuan Wang, Yunyun Cheng ${ }^{\S}$, Junyi Luo, Ting Chen, Qianyun Xi, Jiajie Sun *(C) \\ and Yongliang Zhang *
}

check for

updates

Citation: Xiong, J.; Zhang, H.;

Wang, Y.; Cheng, Y.; Luo, J.; Chen, T.; Xi, Q.; Sun, J.; Zhang, Y. Rno_circ_00 01004 Acts as a miR-709 Molecular Sponge to Regulate the Growth Hormone Synthesis and Cell Proliferation. Int. J. Mol. Sci. 2022, 23 1413. https://doi.org/10.3390/ ijms23031413

Academic Editor: Wolfgang Linert

Received: 28 December 2021

Accepted: 24 January 2022

Published: 26 January 2022

Publisher's Note: MDPI stays neutral with regard to jurisdictional claims in published maps and institutional affiliations.

Copyright: (C) 2022 by the authors. Licensee MDPI, Basel, Switzerland. This article is an open access article distributed under the terms and conditions of the Creative Commons Attribution (CC BY) license (https:// creativecommons.org/licenses/by/ $4.0 /)$.

\author{
College of Animal Science, Guangdong Provincial Key Lab of Agro-Animal Genomics and Molecular Breeding, \\ National Engineering Research Center for Breeding Swine Industry, South China Agricultural University, \\ Guangzhou 510642, China; XJL00LJX@163.com (J.X.); zhanghj089@126.com (H.Z.); 13980686685@163.com (Y.W.); \\ chengyy@jlu.edu.cn (Y.C.); luojunyi@scau.edu.cn (J.L.); allinchen@scau.edu.cn (T.C.); xqy0228@163.com (Q.X.) \\ * Correspondence: jiajiesun@scau.edu.cn (J.S.); zhangyl@scau.edu.cn (Y.Z.); \\ Tel.: +86-139-2515-8841 (J.S.); +86-135-2780-3004 (Y.Z.) \\ + These authors contributed equally to this work. \\ $\ddagger$ Current address: College of Animal Science and Technology, Guangxi University, Nanning 530004, China. \\ $\S$ Current address: NHC Key Laboratory of Radiobiology, School of Public Health, Jilin University, \\ Changchun 130062, China.
}

\begin{abstract}
Background: As a novel type of non-coding RNA with a stable closed-loop structure circular RNA (circRNA) can interact with microRNA (miRNA) and influence the expression of miRNA target genes. However, circRNA involved in pituitary growth hormone $(\mathrm{GH})$ regulation is poorly understood. Our previous study revealed protein kinase $\mathrm{C}$ alpha (PRKCA) as the target gene of miR-709. Currently, the expression and function of rno_circRNA_0001004 in the rat pituitary gland is not clarified; (2) Methods: In this study, both bioinformatics analysis and dual-luciferase report assays showed a target relationship between rno_circRNA_0001004 and miR-709. Furthermore, the rno_circRNA_0001004 overexpression vector and si-circ_0001004 were constructed and transfected into $\mathrm{GH}_{3}$ cells; (3) Results: We found that rno_circRNA_0001004 expression was positively correlated with the PRKCA gene and GH expression levels, while it was negatively correlated with miR-709. In addition, overexpression of rno-circ_0001004 also promoted proliferation and relieved the inhibition of miR-709 in $\mathrm{GH}_{3}$ cells; (4) Conclusions: Our findings show that rno_circ_0001004 acts as a novel sponge for miR-709 to regulate GH synthesis and cell proliferation, and are the first case of discovery of the regulatory role of circRNA_0001004 in pituitary GH.
\end{abstract}

Keywords: pituitary; rno_circ_0001004; miR-709; GH; proliferation

\section{Introduction}

Growth hormone $(\mathrm{GH})$ is a key hormone secreted from the anterior pituitary, and has received much attention as it regulates key physiological functions such as growth and development [1]. Studies have shown that microRNAs (miRNAs) can regulate the synthesis and secretion of GH [2-4]. MiRNAs are small single endogenous RNAs that regulate post-transcriptional silencing of target genes by binding to the $3^{\prime}$-untranslated region (UTR) or open reading frame (ORF) region of target mRNAs [5]. More and more evidence has demonstrated that miRNA functions broadly in development, physiology, and pathology by influencing cell proliferation, cell differentiation, cell migration, apoptosis, metabolism and signal transduction [6-11]. We have previously shown that the miR-709 is highly expressed in the pituitary and inhibits the GH synthesis and suppresses the viability of $\mathrm{GH}_{3}$ cells [12] by targeting Protein Kinase $\mathrm{C}$ alpha (PKCA). Protein Kinase $\mathrm{C}$ $(\mathrm{PKC})$ is a class of phospholipid-dependent kinases that participate in regulation of protein secretion including GH and luteinizing hormone (LH) $[13,14]$, as well as regulating cell proliferation [15]. 
Circular RNA (circRNA) is a special type of non-coding RNA (ncRNA) molecule that, unlike traditional linear RNA, forms covalently closed loop structures generated by premRNA back splicing. CircRNAs are highly stable, abundant and conserved molecules with the characteristics of cell tissue specificity [16] and have received more attention due to their multiple regulation functions in animals and plants [17-19]. Similar to other regulatory ncRNAs, circRNAs play important roles in various biological processes, such as acting as a scaffold in the assembly of protein complexes [20-22], regulating alternative RNA splicing or transcription and RNA-protein interactions [23,24] and functioning as competing endogenous RNA (ceRNA) [25] or microRNA (miRNA) sponges [26-31]. However, reports of circRNAs involved in pituitary GH regulation have been very scarce up to the present [32,33].

The rno_circ_0001004 was firstly discovered in the rat anterior pituitary by using Illumina sequencing [34]. It is generated from exons 9 to 11 of the Wnk2 gene, with a length of $888 \mathrm{bp}$. However, the underlying regulatory role of rno_circ_0001004 in the pituitary remains unknown. Thus, in the present study, the role of rno_circ_0001004 in the regulation of GH and cell proliferation and the circRNA-miRNA-mRNA network were explored and identified.

\section{Results}

\subsection{Characterization of Rno_circ_0001004 in $\mathrm{GH}_{3}$ Cells}

To characterize rno_circ_0001004 in $\mathrm{GH}_{3}$ cells, we firstly detected the expression of rno_circ_0001004. Convergent and divergent primers were designed to amplify the linear or back-splicing products and total RNA from $\mathrm{GH}_{3}$ cells with or without RNase R treatment was subjected to RT-PCR. As expected, endogenous circ_0001004, but not pre-mRNA, was resistant to RNase R digestion (Figure 1A). Sanger sequencing validated the back-spliced junction of rno_circ_0001004 (Figure 1B).

\section{A}

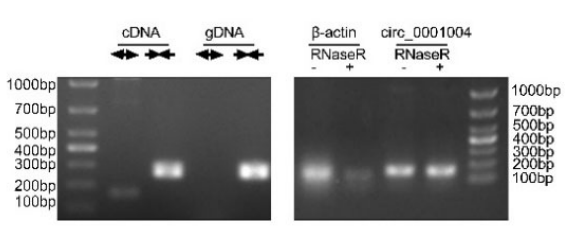

B

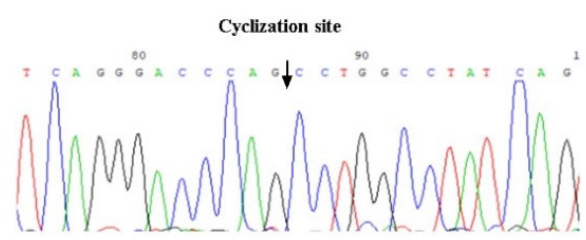

Figure 1. Characterization of rno_circ_0001004 in a $\mathrm{GH}_{3}$ cell. (A) PCR analysis for rno_circ_0001004 in the cDNA and gDNA of a $\mathrm{GH}_{3}$ cell.(left) Total RNA from $\mathrm{GH}_{3}$ cells with or without RNase $\mathrm{R}$ treatment was subjected to RT-PC.(right) (B) The back-splice junction of rno_circ_0001004 was identified by Sanger sequencing.

\subsection{Rno_circ_0001004 Antagonizes miR-709-Mediated Repression of GH Synthesis and Secretion}

Bioinformatics analysis with RNAhybird and miRanda was performed and indicated that rno_circ_0001004 has miR-709 binding sites (Figure 2A). Then, a dual-luciferase reporter assay showed that miR-709 overexpression was able to down-regulate the luciferase activity compared to miR-NC, and this inhibition was eliminated when the rno_circ_0001004 binding site was mutated (Figure 2B). To confirm their target relationship, the rno_circ_0001004 overexpression vector was constructed (Figure 2C), and after transfection into a $\mathrm{GH}_{3}$ cell, rno_circ_0001004 was overexpressed and miR-709 was correspondingly down-regulated (Figure 2D). The results above suggest that rno_circ_0001004 is a molecular sponge for miR-709. Our previous studies demonstrated that miR-709 significantly inhibited the GH synthesis by targeting PKCA [12]. Thus, we further detected the change in $\mathrm{PKC} \alpha$ pathway and GH expression and release. Interestingly, our results show that rno_circ_0001004 obviously increases the mRNA and protein levels of $P K C \alpha$, the phosphorylation of ERK1/2 (Figure 2E,F) and GH protein within cell as well as supernatant, compared to empty vectors (Figure 2F,G). These results confirm that rno_circ_0001004 antagonizes miR-709-mediated repression of the GH synthesis and secretion through the PKC $\alpha$ pathway. 
A

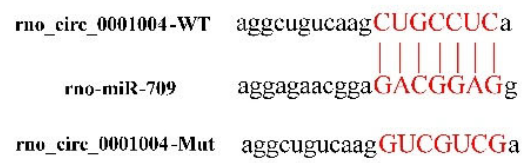

C
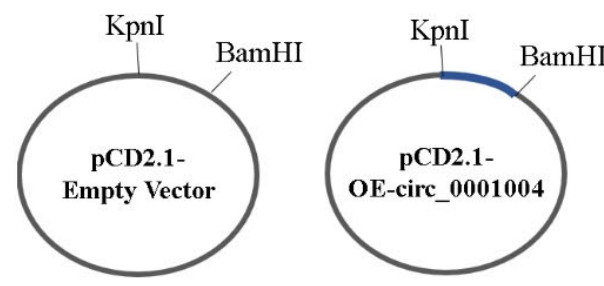

E

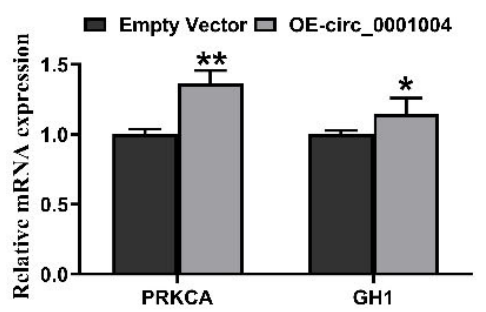

$\mathbf{F}$

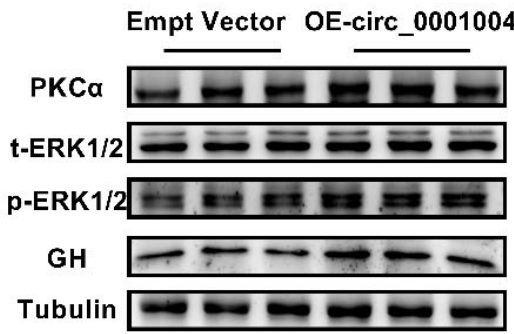

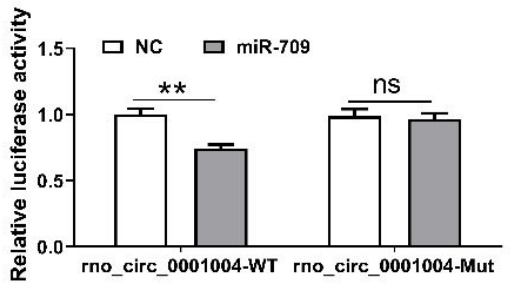

D

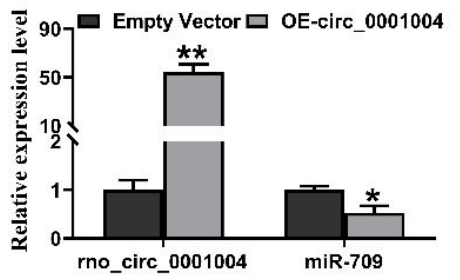

G
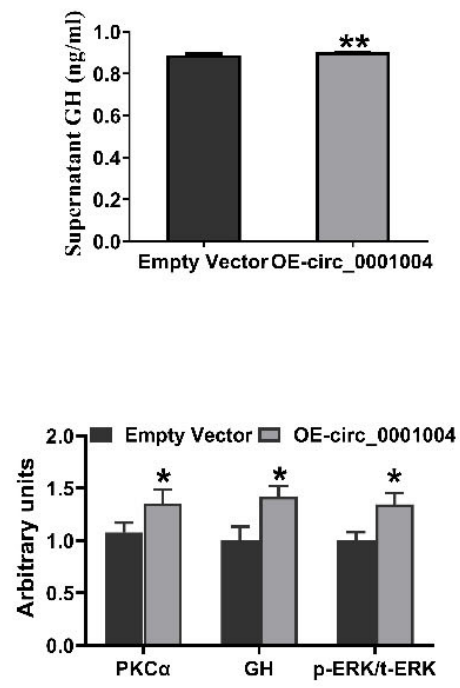

Figure 2. Rno_circ_0001004 antagonizes miR-709-mediated repression the synthesis and secretion of GH. (A) Bioinformatics target prediction. (B) Dual luciferase reporter gene assay verified. (C) Construction of rno_circ_0001004 overexpression vector. (D) Expression of rno_circ_0001004 along with miR-709 in empty vector and overexpression vector in $\mathrm{GH}_{3}$ by qRT-PCR. (E) mRNA level of PKCA and GH1 after transfection of OE-circ_0001004. (F) Western blot evaluation results of PKC $\alpha, \mathrm{t}-\mathrm{ERK} 1 / 2$, $p$-ERK1/2 and GH protein expression following transfection with rno_circ_0001004 in $\mathrm{GH}_{3}$ cells. (G) changes in supernatant GH level: average expression rose from 0.87 to $0.9 \mathrm{ng} / \mathrm{mL} .{ }^{*} p<0.05$; ** $p<0.01)$.

\subsection{Knockdown of Rno_circ_0001004 Suppresses the GH Synthesis and Secretion in $\mathrm{GH}_{3}$ Cell}

In order to further verify the effect of rno_circ_0001004 on GH, we transfected sicirc_0001004 to $\mathrm{GH}_{3}$ cells. As expected, si-circ_0001004 significantly decreased the expression of circ_0001004, while it correspondingly increased the miR-709 expression level, followed by the inhibition of mRNA in PRKCA and GH1 (Figure 3A). Furthermore, a Western blot revealed that the protein expression of $P K C \alpha$, the phosphorylation of ERK1/2, and GH both in cell and supernatant all decreased with the inhibition of circ_0001004 (Figure 3B,C). The above results further confirm that rno_circ_0001004 regulates the synthesis and secretion of $\mathrm{GH}$ by acting as a molecular sponge for miR-709. 
A

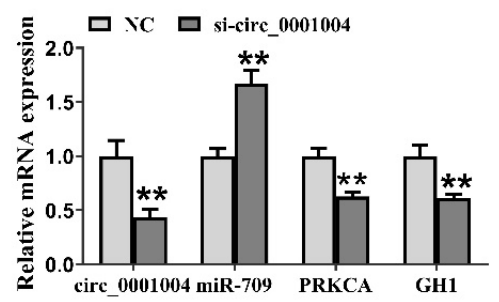

C

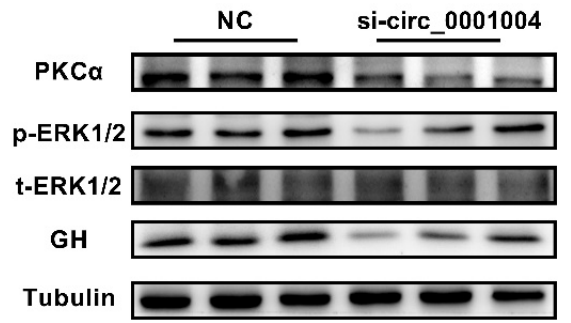

B
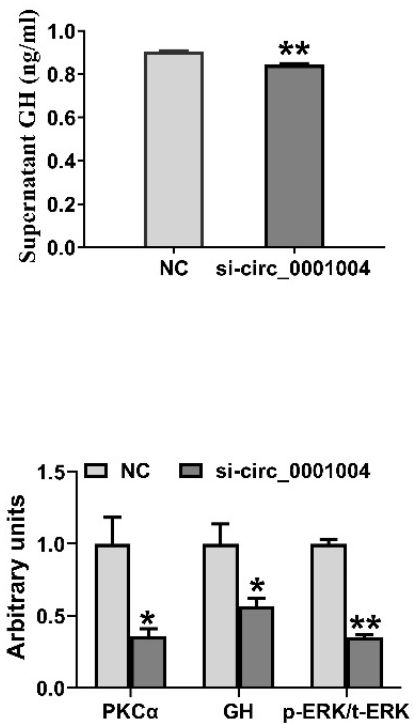

Figure 3. Knockdown of rno_circ_0001004 promoted the GH synthesis and suppressed $\mathrm{GH}_{3}$ cells. (A) The mRNA level of PKCA and GH1 along with circ_0001004 and miR-709 expression after transfection si-circ_0001004. (B) The changes in supernatant GH level after transfection si-circ_0001004. (C) The PKC $\alpha, \mathrm{t}$-ERK1/2, $p$-ERK1/2 and GH protein expression levels in $\mathrm{GH}_{3}$ cells after transfection si-circ_0001004. (* $\left.p<0.05 ;{ }^{* *} p<0.01\right)$.

\subsection{Rno_circ_0001004 Promoted the Viability of $\mathrm{GH}_{3}$ Cells}

Our previous study showed that miR-709 suppressed the viability of $\mathrm{GH}_{3}$ cells [12]. Thus, we performed CCK8 and EdU assays to determine the effect of rno_circ_0001004 on $\mathrm{GH}_{3}$ cell proliferation. Intriguingly, circ_0001004 significantly promoted $\mathrm{GH}_{3}$ cell proliferation (Figure 4A,B). Moreover, PCNA, the key marker of cell proliferation, was markedly up-regulated both in mRNA and protein levels (Figure 4C,D).

A

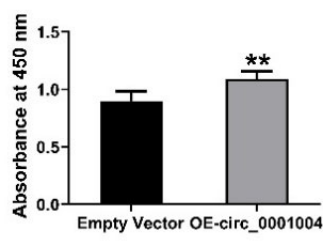

B

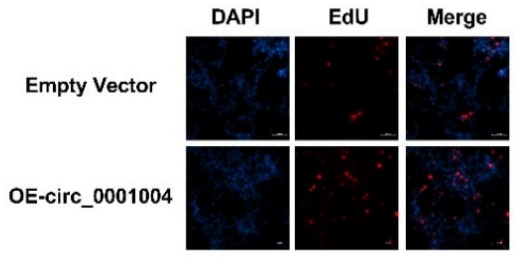

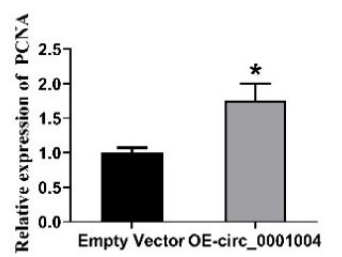

D
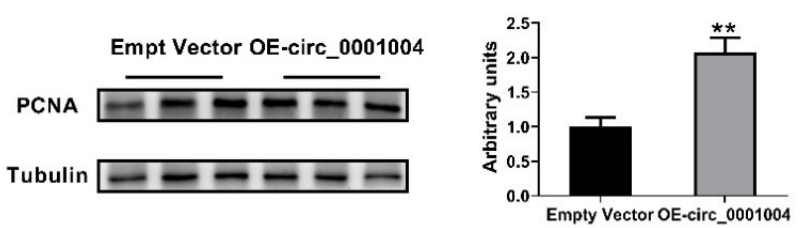

Figure 4. Rno_circ_0001004 promoted the viability of $\mathrm{GH}_{3}$ cells (A) The $\mathrm{GH}_{3}$ proliferation was evaluated with CCK-8 kits. (B) Cell proliferation tested by an EdU assay. (C) PCNA mRNA expression quantified by qRT-PCR. (D) Western blot assay for PCNA protein expression. $\left({ }^{*} p<0.05\right.$; ${ }^{* *} p<0.01$ ).

\subsection{Rno_circ_0001004 Reversed the Inhibition of Cell Proliferation by miR-709}

In order to further confirm the idea that rno_circ_0001004 serves as a ceRNA for miR709 to regulate the viability of $\mathrm{GH}_{3}$ cells, we next co-transfected miR-709 mimics and circ_0001004 into $\mathrm{GH}_{3}$ cells. The results demonstrates that overexpression of miR-709 
obviously inhibits the cell proliferation of $\mathrm{GH}_{3}$, and this inhibition is perfectly rescued by overexpression of rno_circ_0001004, as shown by CCK8 assay (Figure 5A), EdU assay (Figure 5B) and PCNA expression (Figure 5C,D). These results provide more profound evidence that rno_circ_0001004 is a sponge ceRNA for miR-709.

A

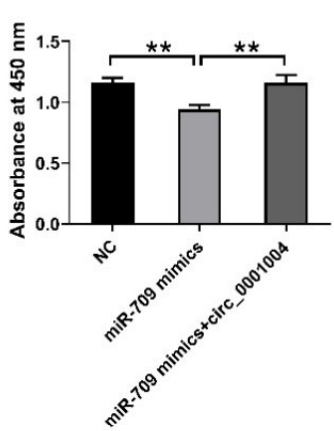

D

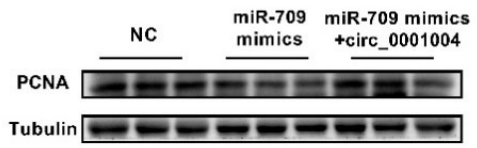

B

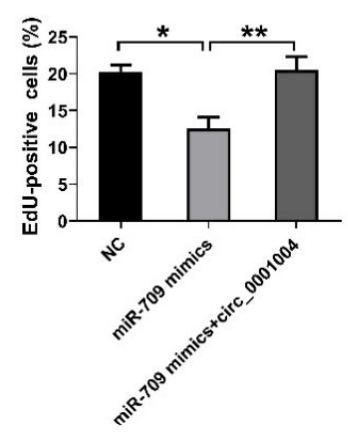

C

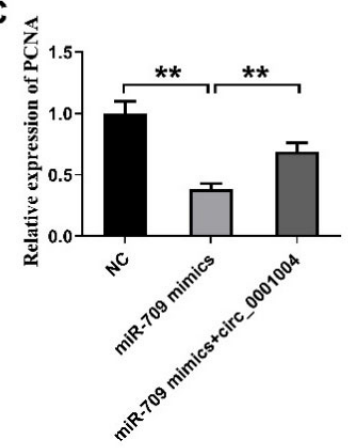

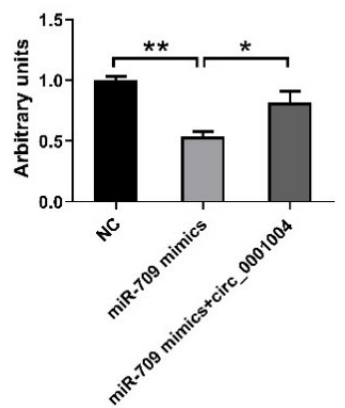

Figure 5. Effects of rno_circ_0001004 in reversing the inhibition of cell proliferation by miR-709. (A) The $\mathrm{GH}_{3}$ proliferation was evaluated with CCK-8 kits. (B) EdU-positive cells. (C) PCNA mRNA expression quantified by qRT-PCR. (D) Western blot assay for PCNA protein expression. $\left({ }^{*} p<0.05\right.$; ** $p<0.01)$.

\section{Discussion}

The pituitary gland, called the 'master gland' of the endocrine system, is the central regulator for growth, reproduction, metabolism and stress response [35]. The anterior pituitary accounts for $80 \%$ of the entire pituitary gland and secretes six major hormones, which are crucial to our physiological well-being [36,37]. As a major hormone in the pituitary gland, GH plays an important role in regulating the growth and metabolism of organisms $[38,39]$.

MiRNAs are a class of small ncRNA with a length of about 22 nucleotides that posttranscriptionally regulate gene expression [40]. MiRNA generally functions primarily by binding to the $3^{\prime}$ untranslated region (UTR) of the target mRNA [41]. They play important roles in essential processes such as cell proliferation, cell apoptosis and cell differentiation $[42,43]$. miRNA was reported to participate in regulating GH. MiR-34b, miR-326, miR-432, miR-548c and miR-570 were found to regulate pituitary cell proliferation [44]. miR126 played an important role in the development of GH-secreting pituitary adenomas [2]. Our previous study showed that miR-709 inhibited the GH synthesis and suppressed the viability of $\mathrm{GH}_{3}$ cells by targeting PRKCA [12].

CircRNAs are derived from the exon or intron region of genes [45]. There are currently three hypothetical models for the mechanism of circRNA formation, including lariatdriven circularization, intron pairing-driven circularization, and RNA binding protein (RBP)-mediated circularization [46]. CircRNAs containing multiple competing miRNA binding sites are likely to act as ceRNA in reducing miRNA activity and up-regulating the expression of miRNA-related target genes [47]. Thousands of strongly and stably expressed circRNAs have been detected [26]. CircFGFR4 promotes the differentiation of myoblasts by binding miR-107 [48]. Circ0005276 can promote the proliferation and migration of 
prostate cancer cells [49]. Circ-ZNF609 regulates nasopharyngeal carcinoma cell growth via modulating miR-188 expression [50]. Some studies have identified circRNAs in the pituitary gland [51-54]. At present, there have been few reports of circRNA regulating GH.

In the present study, we firstly noted that rno_circ_0001004 has the potential to act as miR-709 binding sites. Then, characterization of rno_circ_0001004 was carried out and the target relationship with miR-709 was validated using a dual luciferase assay. To further probe the influence of rno_circ_0001004 on GH, the overexpression of a rno_circ_0001004 vector and si-circ_0001004 were constructed. Next, the genes and proteins in the pathway of miR-709 regulation of GH were all evaluated. The results show that the expression trend of rno_circ_0001004 is almost opposite to that of miR-709, but is consistent with the expression trend of PKC $\alpha, \mathrm{GH}$ and the phosphorylation of ERK1/2. Thus, our findings firstly clarify the molecular mechanism by which rno_circ_001004 can act as a sponge for miR-709 in regulating the synthesis and secretion of $\mathrm{GH}$, providing novel insight into the regulatory mechanism of $\mathrm{GH}$.

Our prior study also found that miR-709 repressed the viability of $\mathrm{GH}_{3}$ cells [12]. Thus, we explored whether rno_circR_0001004 affected the proliferation of $\mathrm{GH}_{3}$ cells. Compared with the empty vector, the rno_circ_0001004 overexpression group can significantly promote the proliferation of $\mathrm{GH}_{3}$ cells, as determined by the CCK-8 assay, PCNA expression and the EdU incorporation assay. Moreover, rno_circ_0001004 was able to perfectly reverse the inhibitory effect of miR-709 on the proliferation of $\mathrm{GH}_{3}$ cells. Therefore, our study reveals that rno_circ_001004 is able to positively regulate $\mathrm{GH}_{3}$ cell viability. These results indicate that rno_circ_0001004 plays an essential role in the regulation GH and pituitary cell proliferation. Furthermore, they lay a foundation for further study to explore the importance of circ_0001004 in regulation of animal and human growth and development.

\section{Materials and Methods}

\subsection{Cell Culture and Transfection}

$\mathrm{GH}_{3}$ cell line (ATCC) was cultured in F12 (Gibco, New York, NY, USA) medium supplemented with 2.5\% fetal bovine serum (FBS) (Gibco, New York, NY, USA), 15\% horse serum (Hyclone, Logan, UT, USA) and 1\% penicillin/streptomycin (Gibco, New York, NY, USA). Hela cells were cultured in PRMI 1640 (Gibco, New York, NY, USA) culture medium with $10 \% \mathrm{FBS}$ and $1 \%$ penicillin/streptomycin. $\mathrm{GH}_{3}$ cells were transfected with miR-709 mimic, rno_circ_0001004 or si-circ0001004 using Lipofectamine 2000 (Invitrogen, Carlsbad, CA, USA). The cells were incubated at $37^{\circ} \mathrm{C}$ in a humidified atmosphere of $5 \% \mathrm{CO}_{2}$.

\subsection{RAN Isolation, cDNA Synthesis, RT-PCR and Sanger Sequencing}

Total RNA was isolated from $\mathrm{GH}_{3}$ cells by Trizol reagent (Invitrogen, Carlsbad, CA, USA) according to the manufacturer's protocol. The cDNAs were obtained by Color Reverse Transcription Kit (with gDNA remover) (EZBioscience, Roseville, CA, USA). Genomic DNA (gDNA) was extracted using a Genomic DNA Isolation Kit (Sangon Biotech, Shanghai, China). Quantification of mRNA, miRNA, circRNA and gDNA was performed by using a SBRY Green PCR Kit (Takara, Tokyo, Japan), primers and Real-Time PCR System (Bio-Rad Laboratories, Inc., Hercules, CA, USA) The circRNA and mRNA levels were normalized to those of $\beta$-actin, while the miR-709 levels were normalized to the U6 and determined by 2-DDCt method. The primer sequences for the amplification of specific primers are listed in supplementary Table S1. Sanger sequencing (chain termination sequencing) is a method of DNA sequencing based upon the selective incorporation of chain-terminating dideoxynucleotides (ddNTPs) during in vitro DNA replication [55].

\subsection{Vector Construction}

The sequence for exons 9-11 of Wnk2 was PCR amplified using primers $\mathrm{F}$ ( $5^{\prime}$-GGGGTA CCTGAAATATGCTATCTTACAGCCTGGCCTATCAGTGGGC- $\left.3^{\prime}\right)$ and R (5'-CGGGATCCT CAAGAAAAAATATATTCACCTGGGTCCCTGAGGCAGC-3'), then cloned into KpnI 
and BamHI restriction sites of a circular expression vector, the pcd2.1-ciR (GENESEED, Guangzhou, China), by digestion to create rno_circ_0001004-overespressing vector.

\subsection{Dual-Luciferase Reporter Assay}

Hela cells were seeded in 96-well cell culture plates. When their confluence reached about $80 \%$, the miR-709 mimic and rno_circ_0001004-Wt or rno_circ_0001004-Mut were co-transfected into cells using Lipofectamine 2000. After incubation for $48 \mathrm{~h}$, the cells were washed with PBS and the luciferase activity was measured by the Dual-GLO luciferase reporter assay system (Promega, Madison, WI, USA) according to the manufacturer's instructions.

\subsection{Evaluation of $\mathrm{GH}_{3}$ Proliferation}

$\mathrm{GH}_{3}$ proliferation was assessed by the cell counting kit-8 (CCK-8) method, 5-ethynyl-2' deoxy uridine (EdU) incorporation assay and proliferating cell nuclear antigen (PCNA) expression. Firstly, the rate of $\mathrm{GH}_{3}$ proliferation was determined with the CCK-8 kit (Bioss, Beijing, China) according to the manufacturer's instructions. The number of viable cells was assessed by measuring the absorbance at $450 \mathrm{~nm}$ using a Synergy 2 Multi-Mode Reader (Bio Tek Instruments, Inc., Winooski, VT, USA). Secondly, DNA synthesis was examined with EdU incorporation assay $\left(\mathrm{YF}^{\circledR} 555\right.$ Click-iT EdU Imaging Kit, Suzhou US EVERBRIGHT, Suzhou, China) to evaluate $\mathrm{GH}_{3}$ proliferation. The EdU positive cells were counted and normalized by the total number of Hoechst 33,342 stained cells. Lastly, $\mathrm{GH}_{3}$ proliferation was evaluated by PCNA expression, which is the auxiliary component of DNA polymerase $\delta$ and constitutes a useful proliferation marker.

\subsection{Western Blot Analysis}

$\mathrm{GH}_{3}$ cells were lysed in a RIPA lysis buffer (Beyotime Institute of Biotechnology, Shanghai, China) containing $1 \mathrm{mM}$ phenyl methane sulfonyl fluoride (PMSF). The concentration of protein was measured using the BCA Protein Assay Kit (Thermo Fisher Scientific, Waltham, MA, USA) according to the manufacturer's instructions. Equal amounts of total protein were separated by SDS-PAGE and transferred to a PVDF membrane in a tris-glycine methanol buffer. The primary antibodies used in this study were as follows: GH monoclonal antibody (sc-374266, Santa Cruz, CA, USA), PKC $\alpha$ polyclonal antibody (BS1577, Bioworld, St. Louis Park, MN, USA), ERK1/2 monoclonal antibody (4695, CST, Danvers, MA, USA), Phospho-ERK1/2 monoclonal antibody (Tyr204) (4370, CST, Danvers, MA, USA), PCNA monoclonal antibody (200947-2E1, ZEN BIO, Chengdu, China) and Tubulin polyclonal antibody (AP0064, Bioworld, St. Louis Park, MN, USA), HRP conjugated goat anti-rabbit IgG (BS13278, Bioworld, St. Louis Park, MN, USA) and HRP conjugated goat anti-mouse IgG (BS12478, Bioworld, St. Louis Park, MN, USA) were used as secondary antibodies. The membranes were incubated with ImmobilonTM Western Chemiluminescent HPR Substrate (Millipore, Burlington, WA, USA) and scanned with a FlourChem M Fluorescent Western Imaging System (Protein Simple, Santa Clara, CA, USA). The protein band density was determined by the software Image J and normalized with a corresponding Tubulin intensity.

\subsection{Quantification of Secretory GH by ELISA}

The concentration of $\mathrm{GH}$ in a cell medium of $\mathrm{GH}_{3}$ cells transfected with rno_circ_0001004 and si-circ_0001004 was determined using the reagents in the Rat Growth Hormone ELISA kit (Enzyme-linked Biotechnology, Shanghai, China) according to the manufacturer's protocols. Color alterations in the wells were read using the 96-well microplate reader (Bio Tek Instruments, Inc., Winooski, VT, USA).

\subsection{Statistics Analysis}

All experimental results are presented as the mean \pm S.E.M, with at least three independent replications. Statistical analysis was performed using SPSS 17.0 software. The 
statistically significant differences among groups were tested by one-way analysis of variance (ANOVA). $p<0.05$ was considered as statistically significant. ${ }^{*} p<0.05 ;{ }^{* *} p<0.01$.

\section{Conclusions}

In summary, our study reveals that rno_circ_0001004 competitively binds miR-709 to regulate the $\mathrm{GH}$ synthesis and cell proliferation in rat pituitary cells (Figure 6). To the best of our knowledge, our findings are the first case to illustrate regulation of GH by circRNA_0001004 and provide novel evidence on the circRNA-miRNA-mRNA network in pituitary cells.

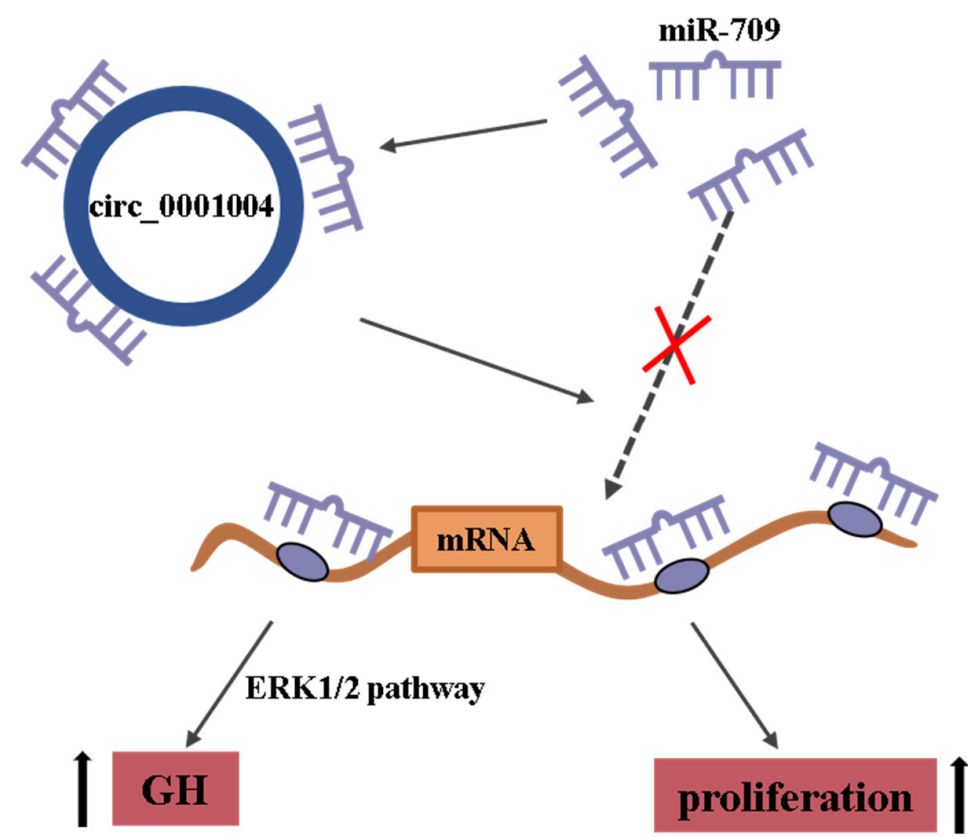

Figure 6. Rno_circ_0001004 has 3 miR-709 binding sites and can act as a miR-709 molecular sponge to regulate $\mathrm{GH}$ synthesis and cell proliferation.

Supplementary Materials: The following supporting information can be downloaded at: https:// www.mdpi.com/article/10.3390/ijms23031413/s1.

Author Contributions: Methodology, Y.Z. and Q.X.; software, J.S.; validation, J.X., H.Z. and Y.W.; data curation, Y.C.; writing—original draft preparation, J.X.; writing-review and editing, Y.Z.; supervision, J.L. and T.C.; project administration, Y.Z. All authors have read and agreed to the published version of the manuscript.

Funding: This research was funded by the National Natural Science Foundation of China, grant numbers 31802156, 32072814 and 32072812; Natural Science Foundation of Guangzhou City, grant numbers 2021A1515011310 and 2020A1515010062.

Institutional Review Board Statement: Not applicable.

Informed Consent Statement: Not applicable.

Data Availability Statement: Not applicable.

Conflicts of Interest: The authors declare no conflict of interest.

\section{References}

1. Nyberg, F. Growth Hormone in the Brain: Characteristics of Specific Brain Targets for the Hormone and Their Functional Significance. Front. Neuroendocrinol. 2000, 21, 330-348. [CrossRef] [PubMed]

2. Mao, Z.G.; He, D.S.; Zhou, J.; Yao, B.; Xiao, W.W.; Chen, C.H.; Zhu, Y.H.; Wang, H.J. Differential expression of microRNAs in GH-secreting pituitary adenomas. Diagn. Pathol. 2010, 5, 79. [CrossRef] [PubMed] 
3. Zhang, Z. Florez Sergio Gutierrez-Hartmann Arthur Martin James, F.; Amendt Brad, A. MicroRNAs Regulate Pituitary Development, and MicroRNA 26b Specifically Targets Lymphoid Enhancer Factor 1 (Lef-1), Which Modulates Pituitary Transcription Factor 1 (Pit-1) Expression. J. Biol. Chem. 2010, 285, 34718-34728. [PubMed]

4. Yu, Z.W.; Gao, W.; Feng, X.Y.; Zhang, J.Y.; Yuan, B. Roles of differential expression of miR-543-5p in GH regulation in rat anterior pituitary cells and GH3 cells. PLoS ONE 2019, 14, e0222340. [CrossRef] [PubMed]

5. Liu, Y.W. MicroRNAs: Genomics, Biogenesis, Mechanism, and Function. Cell 2004, 116, 281-297.

6. Gee, H.E.; Camps, C.; Buffa, F.M.; Colella, S.; Sheldon, H.; Gleadle, J.M.; Ragoussis, J.; Harris, A.L. MicroRNA-10b and breast cancer metastasis. Nature 2008, 455, E8. [CrossRef]

7. Kota, J.; Chivukula, R.R.; O’Donnell, K.A.; Wentzel, E.A.; Montgomery, C.L.; Hwang, H.W.; Chang, T.C.; Vivekanandan, P.; Torbenson, M.; Clark, K.R. Therapeutic delivery of miR-26a inhibits cancer cell proliferation and induces tumor-specific apoptosis. Cell 2009, 137, 1005. [CrossRef]

8. Ma, L.; Teruya-Feldstein, J.; Weinberg, R.A. Tumour invasion and metastasis initiated by microRNA-10b in breast cancer. Nature 2007, 449, 682-688. [CrossRef]

9. Png, K.J.; Halberg, N.; Yoshida, M.; Tavazoie, S.F. A microRNA regulon that mediates endothelial recruitment and metastasis by cancer cells. Nature 2012, 481, 190-194. [CrossRef]

10. Tay, Y.; Zhang, J.; Thomson, A.M.; Bing, L.; Rigoutsos, I. MicroRNAs to Nanog, Oct4 and Sox2 coding regions modulate embryonic stem cell differentiation. Nature 2008, 455, 1124. [CrossRef]

11. Felekkis, K.; Touvana, E.; Stefanou, C.; Deltas, C. MicroRNAs: A newly described class of encoded molecules that play a role in health and disease. Hippokratia 2010, 14, 236-240. [PubMed]

12. Cheng, Y.; Chen, T.; Song, J.; Qi, Q.; Zhang, Y. miR-709 inhibits GHRP6 induced GH synthesis by targeting PRKCA in pituitary Mol. Cell. Endocrinol. 2020, 506, 110763. [CrossRef] [PubMed]

13. Grey, C.L.; Chang, J.P. Differential modulation of ghrelin-induced GH and LH release by PACAP and dopamine in goldfish pituitary cells. Gen. Comp. Endocrinol. 2013, 191, 215-224. [CrossRef] [PubMed]

14. Pemberton, J.G.; Orr, M.E.; Stafford, J.L.; Chang, J.P. PI3K signalling in GnRH actions on dispersed goldfish pituitary cells: Relationship with PKC-mediated LH and GH release and regulation of long-term effects on secretion and total cellular hormone availability. Gen. Comp. Endocrinol. 2014, 205, 268-278. [CrossRef]

15. Petiti, J.P.; Gutiérrez, S.; De Paul, A.L. Andreoli: GH3B6 Pituitary Tumor Cell Proliferation is Mediated by PKC $\alpha$ and PKC $\varepsilon$ via ERK 1/2-dependent Pathway. Cell Physiol. Biochem. 2010, 26, 135-146. [CrossRef]

16. Meng, S.; Zhou, H.; Feng, Z.; Xu, Z.; Ying, T.; Li, P.; Wu, M. CircRNA: Functions and properties of a novel potential biomarker for cancer. Mol. Cancer 2017, 16, 94. [CrossRef]

17. Chen, L.L.; Yang, L. Regulation of circRNA biogenesis. RNA Biol. 2015, 12, 381-388. [CrossRef]

18. Salzman, J.; Gawad, C.; Wang, P.L.; Lacayo, N.; Brown, P.O. Circular RNAs Are the Predominant Transcript Isoform from Hundreds of Human Genes in Diverse Cell Types. PLoS ONE 2012, 7, e30733. [CrossRef]

19. Ye, C.Y.; Chen, L.; Liu, C.; Zhu, Q.H.; Fan, L. Widespread noncoding circular RNAs in plants. New Phytol. 2015, 208, 88-95. [CrossRef]

20. Du, W.W.; Fang, L.; Yang, W.; Wu, N.; Awan, F.M.; Yang, Z.; Yang, B.B. Induction of tumor apoptosis through a circular RNA enhancing Foxo3 activity. Cell Death Differ. 2017, 24, 357-370. [CrossRef]

21. Du, W.W.; Yang, W.; Liu, E.; Yang, Z.; Yang, B.B. Foxo3 circular RNA retards cell cycle progression via forming ternary complexes with p21 and CDK2. Nucleic Acids Res. 2016, 44, gkw027. [CrossRef] [PubMed]

22. Zeng, Y.; Du, W.W.; Wu, Y.; Yang, Z.; Awan, F.M.; Li, X.; Yang, W.; Zhang, C.; Yang, Q.; Yee, A.; et al. A Circular RNA Binds To and Activates AKT Phosphorylation and Nuclear Localization Reducing Apoptosis and Enhancing Cardiac Repair. Theranostics 2017, 7, 3842-3855. [CrossRef] [PubMed]

23. Ashwal-Fluss, R.; Meyer, M.; Pamudurti, N.R.; Ivanov, A.; Bartok, O.; Hanan, M.; Evantal, N.; Memczak, S.; Rajewsky, N.; Kadener, S. circRNA Biogenesis Competes with Pre-mRNA Splicing-ScienceDirect. Mol. Cell 2014, 56, 55-66. [CrossRef] [PubMed]

24. Salzman, J. Circular RNA Expression: Its Potential Regulation and Function. Trends Genet. 2016, 32, 309-316. [CrossRef]

25. Huang, M.; Zhong, Z.; Lv, M.; Shu, J.; Tian, Q.; Chen, J. Comprehensive analysis of differentially expressed profiles of lncRNAs and circRNAs with associated co-expression and ceRNA networks in bladder carcinoma. Oncotarget 2016, 7, 47186. [CrossRef]

26. Memczak, S.; Jens, M.; Elefsinioti, A.; Torti, F.; Krueger, J.; Rybak, A.; Maier, L.; Mackowiak, S.D.; Gregersen, L.H.; Munschauer, M.; et al. Circular RNAs are a large class of animal RNAs with regulatory potency. Nature 2013, 495, 333-338. [CrossRef] [PubMed]

27. Hansen, T.B.; Jensen, T.I.; Clausen, B.H.; Bramsen, J.B.; Finsen, B.; Damgaard, C.K.; Kjems, J. Natural RNA circles function as efficient microRNA sponges. Nature 2013, 495, 384-388. [CrossRef]

28. Lei, P.; Chen, G.; Zhu, Z.; Shen, Z.; Du, C.; Zang, R.; Yang, S.; Hua, X.; Li, H.; Xu, X. Circular RNA ZNF609 functions as a competitive endogenous RNA to regulate AKT3 expression by sponging miR-150-5p in Hirschsprung's disease. Oncotarget 2017, 8,808 .

29. Li, F.; Zhang, L.; Li, W.; Deng, J.; Zheng, J.; An, M.; Lu, J.; Zhou, Y. Circular RNA ITCH has inhibitory effect on ESCC by suppressing the Wnt/ $\beta$-catenin pathway. Oncotarget 2015, 6, 6001. [CrossRef]

30. Wang, K.; Long, B.; Liu, F.; Wang, J.X.; Li, P.F. A circular RNA protects the heart from pathological hypertrophy and heart failure by targeting miR-223. Eur. Heart J. 2016, 37, ehv713. [CrossRef] [PubMed] 
31. Zheng, Q.; Bao, C.; Guo, W.; Li, S.; Chen, J.; Chen, B.; Luo, Y.; Lyu, D.; Li, Y.; Shi, G. Circular RNA profiling reveals an abundant circHIPK3 that regulates cell growth by sponging multiple miRNAs. Nat. Commun. 2016, 7, 11215. [CrossRef] [PubMed]

32. Du, Q.; Zhang, W.; Feng, Q.; Hao, B.; Cheng, C.; Cheng, Y.; Li, Y.; Fan, X.; Chen, Z. Comprehensive circular RNA profiling reveals that hsa_circ_0001368 is involved in growth hormone-secreting pituitary adenoma development. Brain Res. Bull. 2020, $161,65-77$. [CrossRef] [PubMed]

33. Yu, Z.W.; Ren, W.Z.; Wang, T.; Zhang, W.D.; Yuan, B. CircAgtpbp1 Acts as a Molecular Sponge of miR-543-5p to Regulate the Secretion of GH in Rat Pituitary Cells. Animals 2021, 11, 558. [CrossRef] [PubMed]

34. Han, D.X.; Sun, X.L.; Fu, Y.; Wang, C.J.; Liu, J.B.; Jiang, H.; Gao, Y.; Chen, C.Z.; Yuan, B.; Zhang, J.B. Identification of long non-coding RNAs in the immature and mature rat anterior pituitary. Sci. Rep. 2017, 7, 17780. [CrossRef]

35. Scully, K.M.; Rosenfeld, M.G. Pituitary Development: Regulatory Codes in Mammalian Organogenesis. Science 2002, 295, 2231-2235. [CrossRef]

36. Haggerjohnson, G. An Introduction to Behavioral Endocrinology. Q. Rev. Biol. 2011, 2, $273-282$.

37. Tissier, P.; Hodson, D.J.; Lafont, C.; Fontanaud, P.; Mollard, P. Anterior pituitary cell networks. Front. Neuroendocrinol. 2012, 33, 252-266. [CrossRef]

38. Isaksson, O.; Lindahl, A.; Nilsson, A.; Isgaard, J. Mechanism of the stimulatory effect of growth hormone on longitudinal bone growth. Endocr. Rev. 1987, 8, 426-438. [CrossRef] [PubMed]

39. Salomon, F.; Cuneo, R.C. The effects of treatment with recombinant human growth hormone on body composition and metabolism. N. Engl. J. Med. 1989, 321, 1797. [CrossRef]

40. Carthew, R.W.; Sontheimer, E.J. Origins and mechanisms of miRNAs and siRNAs. Cell 2009, 136, 642-655. [CrossRef]

41. He, L.; Hannon, G.J. MicroRNAs: Small RNAs with a big role in gene regulation. Nat. Rev. Genet. 2004, 5, 522-531. [CrossRef] [PubMed]

42. Miska, E.A. How microRNAs control cell division, differentiation and death. Curr. Opin. Genet. Dev. 2005, 15, 563-568. [CrossRef]

43. Zamore, P.; Haley, B. Ribo-gnome: The Big World of Small RNAs. Science 2005, 309, 1519-1524. [CrossRef] [PubMed]

44. Daniela, D.A.; Dario, P.; Paula, M.; Magali, R.; Anne, W.; Gerald, R.; Monica, F.; Maria, C.C.; Jacqueline, T.; Alfredo, F. Altered microRNA expression profile in human pituitary GH adenomas: Down-regulation of miRNA targeting HMGA1, HMGA2, and E2F1. J. Clin. Endocrinol. Metab. 2012, 97, E1128-E1138.

45. Xiang, L.; Li, Y.; Chen, L.L. The Biogenesis, Functions, and Challenges of Circular RNAs. Mol. Cell 2018, 71, 428-442.

46. Jeck, W.R.; Sorrentino, J.A.; Wang, K.; Slevin, M.K.; Burd, C.E.; Liu, J.; Marzluff, W.F.; Sharpless, N.E. Circular RNAs are abundant, conserved, and associated with ALU repeats. Rna 2013, 19, 141-157. [CrossRef]

47. Qu, S.; Zhong, Y.; Shang, R.; Zhang, X.; Song, W.; Kjems, J.; Li, H. The emerging landscape of circular RNA in life processes. RNA Biol. 2017, 14, 992-999. [CrossRef]

48. Li, H.; Wei, X.; Yang, J.; Dong, D.; Hao, D.; Huang, Y.; Lan, X.; Plath, M.; Lei, C.; Ma, Y. circFGFR4 Promotes Differentiation of Myoblasts via Binding miR-107 to Relieve Its Inhibition of Wnt3a. Mol. Ther. Nucleic Acids 2018, 11, 272-283. [CrossRef]

49. Feng, Y.; Yang, Y.; Zhao, X.; Fan, Y.; Zhou, L.; Rong, J.; Yu, Y. Circular RNA circ0005276 promotes the proliferation and migration of prostate cancer cells by interacting with FUS to transcriptionally activate XIAP. Cell Death Dis. 2019, 10, 792. [CrossRef]

50. Li, M.; Li, Y.; Yu, M. CircRNA ZNF609 Knockdown Suppresses Cell Growth via Modulating miR-188/ELF2 Axis in Nasopharyngeal Carcinoma. OncoTargets Ther. 2020, 13, 2399-2409. [CrossRef]

51. Guo, H.X.; Yuan, B.; Su, M.T.; Zheng, Y.; Zhang, J.B. Identification of Circular RNAs in the Anterior Pituitary in Rats Treated with GnRH. Animals 2021, 11, 2557. [CrossRef] [PubMed]

52. Han, D.X.; Wang, C.J.; Sun, X.L.; Liu, J.B.; Zhang, J.B. Identification of circular RNAs in the immature and mature rat anterior pituitary. J. Endocrinol. 2019, 240, 393-402. [CrossRef] [PubMed]

53. Li, C.; Li, X.; Ma, Q.; Zhang, X.; Cao, Y.; Yao, Y.; You, S.; Wang, D.; Quan, R.; Hou, X. Genome-wide analysis of circular RNAs in prenatal and postnatal pituitary glands of sheep. Sci. Rep. 2017, 7, 16143. [CrossRef] [PubMed]

54. Zhang, H.; Hu, B.; Xiong, J.; Chen, T.; Zhang, Y. Genomewide analysis of circular RNA in pituitaries of normal and heat-stressed sows. BMC Genom. 2019, 20, 1013. [CrossRef] [PubMed]

55. Sanger, F.; Nicklen, S.; Coulson, A.R. DNA sequencing with chain-terminating inhibitors. Proc. Natl. Acad. Sci. USA 1977, 74, 5463-5467. [CrossRef] [PubMed] 